\title{
Lung cancer related to occupational exposure: an integrative review
}

\author{
Câncer de pulmão relacionado à exposição ocupacional: revisão integrativa \\ Cáncer de pulmón relacionado con la exposición ocupacional: revisión integrativa
}

\section{Christiane Brey ${ }^{\mathrm{a}, \mathrm{b}}$ \\ Fernanda Thaysa Gouveiac \\ Brenda Silva Silvad \\ Leila Maria Mansano Sarquis ${ }^{a, b}$ \\ Fernanda Moura D'Almeida Miranda ${ }^{a, b}$ \\ Dario Consonnie}

\section{How to cite this article:}

Brey C, Gouveia FT, Silva BS, Sarquis LMM, Miranda FMA Consonni D. Lung cancer related to occupational exposure: an integrative review. Rev Gaúcha Enferm. 2020;41:e20190378. doi: https://doi. org/10.1590/1983-1447.2020.20190378
- Universidade Federal do Paraná (UFPR), Programa de Pós-Graduação em Enfermagem. Curitiba, Paraná, Brasil.

- Instituto Federal do Paraná (IFPR), Graduação em Enfermagem. Palmas, Paraná, Brasil.

' Hospital Pilar, Coordenação de Enfermagem. Curitiba, Paraná, Brasil.

¿ Hospital Erasto Gaertner, Coordenação de Enfermagem. Curitiba, Paraná, Brasil.

Università degli Studi di Milano (UNIMI). Clinica De Lavoro. Milão, Lombardia, Itália.

\section{ABSTRACT}

Objective: To identify in the literature the carcinogenic agents found in the work environment, the occupations and the risk for lung cancer.

Method: A descriptive and analytical study of the Integrative Literature Review type was carried out in national and international databases from the last ten years in the period from 2009 to 2018, concerning 32 studies referring to association between carcinogenic substances to which the worker is exposed and lung cancer.

Results: Nine (28.1\%) publications originated in China and only one in Brazil. The most exposed workers were from the secondary sector, $50 \%$ being from industry and $6.2 \%$ from construction, mostly male. Asbestos and silica stood out among the carcinogenic substances most associated with lung cancer risk, accounting for $37.5 \%$ and $28.1 \%$, respectively.

Conclusions: The association between occupational exposure and the risk for lung cancer was characterized in this research by the substantial scientific evidence from the described studies that confirm this association.

Keywords: Lung neoplasms. Occupational exposure. Carcinogens. Carcinogenic substances, products and materials.

\section{RESUMO}

Objetivo: Identificar na literatura os agentes carcinogênicos presentes no ambiente ocupacional, as ocupações e o risco do câncer de pulmão.

Método: Estudo descritivo e analítico de revisão integrativa realizada em base de dados nacionais e internacionais dos últimos dez anos, entre 2009 e 2018, compreendendo 32 estudos referentes à associação entre câncer de pulmão e substâncias carcinogênicas de exposição ocupacional.

Resultados: Nove $(28,1 \%)$ publicações originadas na China e apenas uma brasileira. Os trabalhadores mais expostos foram do setor secundário, sendo 50\% da indústria e 6,2\% da construção civil, em sua maioria do sexo masculino. 0 amianto e a sílica sobressaíram-se entre as substâncias carcinogênicas mais associadas ao risco de câncer de pulmão correspondendo a 37,5\% e 28,1\%, respectivamente.

Conclusões: A associação entre a exposição ocupacional e o risco de câncer de pulmão ficou caracterizada nesta pesquisa pelas substanciais evidências científicas dos estudos descritos que confirmam essa associação.

Palavras-chave: Neoplasias pulmonares. Exposição ocupacional. Carcinógenos. Substâncias, produtos e materiais carcinogênicos

\section{RESUMEN}

Objetivo: Identificar en la literatura los agentes cancerígenos presentes en el entorno laboral, las ocupaciones y el riesgo de cáncer de pulmón

Método: Estudio descriptivo y analítico de una revisión integradora realizada en una base de datos nacional e internacional de los últimos diez años, entre 2009 y 2018, que comprende 32 estudios referidos a la vinculación entre el cáncer de pulmón y las sustancias cancerígenas de exposición ocupacional.

Resultados: Nueve $(28,1 \%)$ publicaciones tuvieron su origen en China y solo una en Brasil. Los trabajadores más expuestos pertenecían al sector secundario, el 50\% a la industria y un 6,2\% a la construcción, siendo en su mayoría hombres. El asbesto y la sílice se destacaron entre las sustancias cancerígenas más asociadas con el riesgo de cáncer de pulmón, con índices de 37,5\% y el $28,1 \%$, respectivamente.

Conclusiones: La vinculación entre la exposición ocupacional y el riesgo de cáncer de pulmón se caracterizó en esta investigación por la evidencia científica sustancial de los estudios descriptos que confirman esta asociación.

Palabras clave: Neoplasias pulmonares. Exposición profesional. Carcinógenos. Sustancias, productos y materiales carcinogénicos. 


\section{口INTRODUCTION}

Lung cancer is the most common malignant tumor worldwide, with an increase of $2 \%$ per year in its worldwide incidence ${ }^{(1)}$. Global estimates indicated an incidence of 2.1 million new cases of lung cancer for 2018, with 1.8 million deaths, representing about one fifth (18.4\%) of all cancer deaths worldwide ${ }^{(2)}$.

In Brazil, there is an estimate of 18,740 new cases of lung cancer among men and of 12,530 in women for each year of the 2018-2019 biennium. It is the second most frequent tumor among men, corresponding to an estimated risk of 18.16 new cases per 100,000 men; and a risk of 11.81 per 100,000 women, occupying the fourth position ${ }^{(3)}$.

In 90\% of the diagnosed cases, lung cancer is associated with the consumption of tobacco derivatives. (1) Genetic susceptibility and comorbidities also contribute to the development of the disease ${ }^{(4)}$. Moreover, carcinogenesis is a complex process that involves the participation of hereditary and environmental risk factors, such as food, smoking, occupation and exposure to radiation and chemical agents in the environments ${ }^{(5)}$.

The concentration of carcinogens is almost always higher in the work environments than in extra-work environments ${ }^{(6)}$. According to assessments done by the International Labor Organization (ILO), approximately 440,000 people died worldwide in 2005 as a result of exposure to dangerous substances at work. More than $70 \%$ of these, that is, approximately 315 thousand people, died of work-related cancer(6).

About one worker dies every 30 seconds in the world due to exposure to toxic chemicals, pesticides, radiation, and other harmful substances. In addition, industries and companies are often held responsible for failing to protect workers from toxic exposures and for denying treatment to workers who have been affected in any way by exposures ${ }^{(7)}$.

Despite the strong relationship between lung cancer and smoking, several substances and occupational activities are related to lung cancer development. During the $20^{\text {th }}$ century, numerous carcinogenic substances, more precisely 1,013 , found in different work environments were identified and classified by the International Agency for Research on Cancer (IARC). The IARC permanently reviews the scientific literature and promotes studies on the carcinogenicity of chemical substances and industrial processes, classifying them into four categories with regard to the carcinogenic potential for humans: Group 1, when the substance is carcinogenic to humans; Group 2a, when the substance is probably carcinogenic; Group 2b, when the substance is possibly carcinogenic; Group 3, when the substance is not classifiable as a carcinogen; and Group 4, when the substance is probably not carcinogenic ${ }^{(8)}$.

IARC's Working Group considered that exposure to arsenic, inorganic arsenic compounds, beryllium, beryllium, cadmium, chromium-VI compounds, nickel compounds, asbestos (chrysotile, crocidolite, amosite, tremolite, actinolite and amphibole) and dust crystalline silica is associated with lung cancer, as well as exposure to polycyclic aromatic hydrocarbons (PAH), gasification and coke production, aluminum production, tar and asphalt blankets, Bis (chloromethyl)/chloromethyl/metiether ether ${ }^{(6)}$.

In addition to the carcinogenic substances inherent to the occupational activities, occupational exposure to (passive) smoking increases the risks of workers exposed to the development of the same diseases that active smoking produces, albeit to a lesser extent. In 2008, the percentage of passive smokers in the workplace, among people aged 15 and over, was 24.4\%. 2015 data show an important reduction, to $14.4 \%$, which represents about 7.5 million people(9).

The Ministry of Labor, in Brazil, published in 2014 the National List of Carcinogenic Agents for Humans (Lista Nacional de Agentes Cancerígenos para Humanos, LINACH), which was classified into three groups: carcinogens to human beings; probably carcinogenic to human beings; and possibly carcinogenic to human beings ${ }^{(10)}$.

In the first group, there are agents such as benzene, a chemical substance found in petroleum, gasoline, coal burning and solvents. Trichlorethylene, a chemical agent used to make solvents, is also listed as a carcinogen, as is the drug azathioprine, which has anti-leukemic, anti-inflammatory and immunosuppressive properties, among other agents ${ }^{(10)}$.

In the second group, agents such as the azacitidine are listed, indicated for treating Myelodysplastic syndrome, the cisplatin antineoplastic agent, chloral and chloral hydrate, dimethyl sulfate, among others. In the third group, products such as acetamide, ethyl acrylate, lead, chloroform, and styrene can be found, used in the production of polyesters for manufacturing plastic packaging and disposable materials ${ }^{(10)}$.

Although scientific publications have advanced in understanding and investigating the association between lung cancer and exposure to carcinogenic substances found in the workplace, there is a need for further studies on this topic, due to the importance of the topic to public health and of the worker. 
The scarce discussion in the national literature points to the need to identify scientific evidence of the relationship between carcinogenic agents in the workplace and the risk for developing lung cancer.

To this end, this research was based on the following question: What is the association between carcinogenic agents to which the worker is exposed and lung cancer? Aiming to identify in the literature the carcinogenic agents found in the occupational environment, the occupations and the risk for lung cancer.

\section{$\square$ METHOD}

A descriptive and analytical study of the Integrative Literature Review type. The integrative literature review is a method that provides the synthesis of knowledge and the incorporation of the applicability of results of significant studies in practice ${ }^{(11)}$.

To structure this review, 6 methodological stages were followed ${ }^{(12)}$ : identifying the theme and selecting the hypothesis or research question; establishing criteria for inclusion and exclusion of studies or search in the literature; defining the information to be extracted from the selected studies, categorization of the studies; evaluating studies included in the integrative review; interpreting the results; presenting the knowledge-related review or synthesis.

National and international journals from the last ten years were included, with a historical cut between January $1^{\text {st }}$, 2009 and September 21 $1^{\text {st }}, 2018$, original articles, reflections and integrative and systematic reviews that were freely available and in full text, in Portuguese, English, Spanish and Italian languages, which had the term "lung cancer" or its synonym "lung neoplasm" in its title, in the abstract or in the descriptors, and which correlated in its text the exposure to carcinogenic agents at work and the lung cancer. Theses, dissertations and experience reports were excluded.

Data search took place between September and October 2018, under an electronic form, in the database portals: Virtual Health Library (Biblioteca Virtual em Saúde, BVS), National Library of Medicine (PubMed) and Elton Bryson Stephens Company (EBSCO). The following descriptors were used: Lung Neoplasms; Occupational Exposure; Carcinogens; Carcinogenic Substances Products and Materials

For this research, we used the search strategies described in Chart 1 and crossings of descriptors with the Boolean operators AND and $O R$.
The search was delimited by title, keywords or descriptors and summary, in order to demarcate the set of documents to be tracked.

The search identified 2,232 scientific articles selected by the inclusion criteria as previously established. Figure 1 illustrates the flowchart of the selection process of the studies that made up the sample according to the Preferred Reporting Items for Systematic Review and a Meta-Analyses $(\text { PRISMA) })^{(13)}$.

Each summary of the articles found was read, highlighting those that corresponded to the objective proposed in this study. To organize the data, the researchers prepared a data collection spreadsheet in Microsoft Excel 2013 containing the following: author, year, title, type of study, and considerations. 148 articles were selected for full reading, following the exclusion criteria. Of these, 32 articles that were part of the final analysis were included, as they clearly answered the research question.

The analysis of the articles observed the concepts covered in each article and made a comparison between them, so that the researchers acquired an updated and general view of the theme. For greater clarity in the presentation of the data, an instrument was developed to ensure all important data and minimize errors. It contained the identification of the author, year of publication and country where it was published, title of the study, objective of the study, methodological design, number of participants, level of evidence, exposure, outcome and periodical of the publication.

The level of evidence in the studies was classified through the quality of the evidence into seven levels ${ }^{(14)}$. At level I, the evidence comes from a systematic review or meta-analysis of randomized controlled clinical trials or from clinical guidelines based on systematic reviews of randomized controlled clinical trials; level II, evidence derived from at least one well-designed randomized controlled clinical trial; level III, evidence from well-designed clinical trials without randomization; level IV, evidence from well-designed cohort and case-control studies; level $V$, evidence of systematic review of descriptive and qualitative studies; level $\mathrm{VI}$, evidence from a single descriptive or qualitative study; level VII, evidence of opinion of authorities or report of expert committees. The knowledge of evidence classification systems supports the researcher in the critical evaluation of results obtained from researches.

After systematizing the data, a critical analysis was carried out on the association between risk for lung cancer and carcinogenic substances found in the workplace. 


\begin{tabular}{|c|c|c|c|}
\hline Portal & Search strategy & $\mathbf{N}$ & Total \\
\hline \multirow{4}{*}{ BVS } & $\begin{array}{l}\text { tw:(lung neoplasm AND (carcinogens OR carcinogenic substances products } \\
\text { and materials)) }\end{array}$ & 18 & \multirow{4}{*}{1,028} \\
\hline & tw:(lung neoplasm AND occupational exposure) & 912 & \\
\hline & $\begin{array}{l}\text { tw:(occupational exposure AND (carcinogens OR carcinogenic substances } \\
\text { products and materials)) }\end{array}$ & 97 & \\
\hline & $\begin{array}{l}\text { tw:(lung neoplasm AND occupational exposure AND (carcinogens OR } \\
\text { carcinogenic substances products and materials)) }\end{array}$ & 1 & \\
\hline \multirow{4}{*}{ EBSCO } & $\begin{array}{l}\text { (lung neoplasm AND (carcinogens OR carcinogenic substances products } \\
\text { and materials)) }\end{array}$ & 172 & \multirow{4}{*}{598} \\
\hline & (lung neoplasm AND occupational exposure) & 153 & \\
\hline & $\begin{array}{l}\text { (occupational exposure AND (carcinogens OR carcinogenic substances } \\
\text { products and materials)) }\end{array}$ & 233 & \\
\hline & $\begin{array}{l}\text { (lung neoplasm AND occupational exposure AND (carcinogens OR } \\
\text { carcinogenic substances products and materials)) }\end{array}$ & 40 & \\
\hline \multirow{4}{*}{ PUBMED } & $\begin{array}{l}\text { ("lung neoplasm" [MeSH Terms] AND ("carcinogens" [MeSH Terms] OR } \\
\text { carcinogenic substances products and materials")) }\end{array}$ & 194 & \multirow{4}{*}{606} \\
\hline & ("lung neoplasm" [MeSH Terms] AND ("occupational exposure" [MeSH Terms])) & 141 & \\
\hline & $\begin{array}{l}\text { ("Occupational exposure" [MeSH Terms] AND ("carcinogens" [MeSH Terms] OR } \\
\text { carcinogenic substances products and materials")) }\end{array}$ & 208 & \\
\hline & $\begin{array}{l}\text { ("lung neoplasm" [MeSH Terms] AND ("Occupational exposure" [MeSH Terms] } \\
\text { AND ("carcinogens" [MeSH Terms] OR carcinogenic substances products } \\
\text { and materials")) }\end{array}$ & 63 & \\
\hline
\end{tabular}

Chart 1 - Search strategy and crossings in databases with the controlled descriptors and Boolean operators used Source: Research data, 2018

\section{RESULTS}

32 articles were included regarding the association between carcinogenic substances to which the worker is exposed and lung cancer. Among the selected studies, 12 (37.5\%) were carried out on the Asian continent, with a higher prevalence in China with nine (28.1\%) publications. From the European continent, 12 (37.5\%) of the studies were included and five (15.6\%) from North America. Low production in South America stands out with only one (3.1\%) publication from Brazil and one (3.1\%) from Argentina.
22 productions in the IV evidence level were identified; four were classified as studies of level $V$ and six with evidence in level VI. Regarding the study type, ten (31.2\%) are cohort studies; 12 (37.5\%) are case-control studies; seven (21.8\%) review articles, three $(9.3 \%)$ integrative reviews (IR), one (3.1\%) systematic review (RS) of a cohort and case-control study and three (9.3\%) meta-analyses. The rest are two descriptive studies (6.2\%) and one is an analytical cross-sectional study (3.1\%).

With regard to the participants that are involved in the studies, there was variability in the quantity and characteristics 


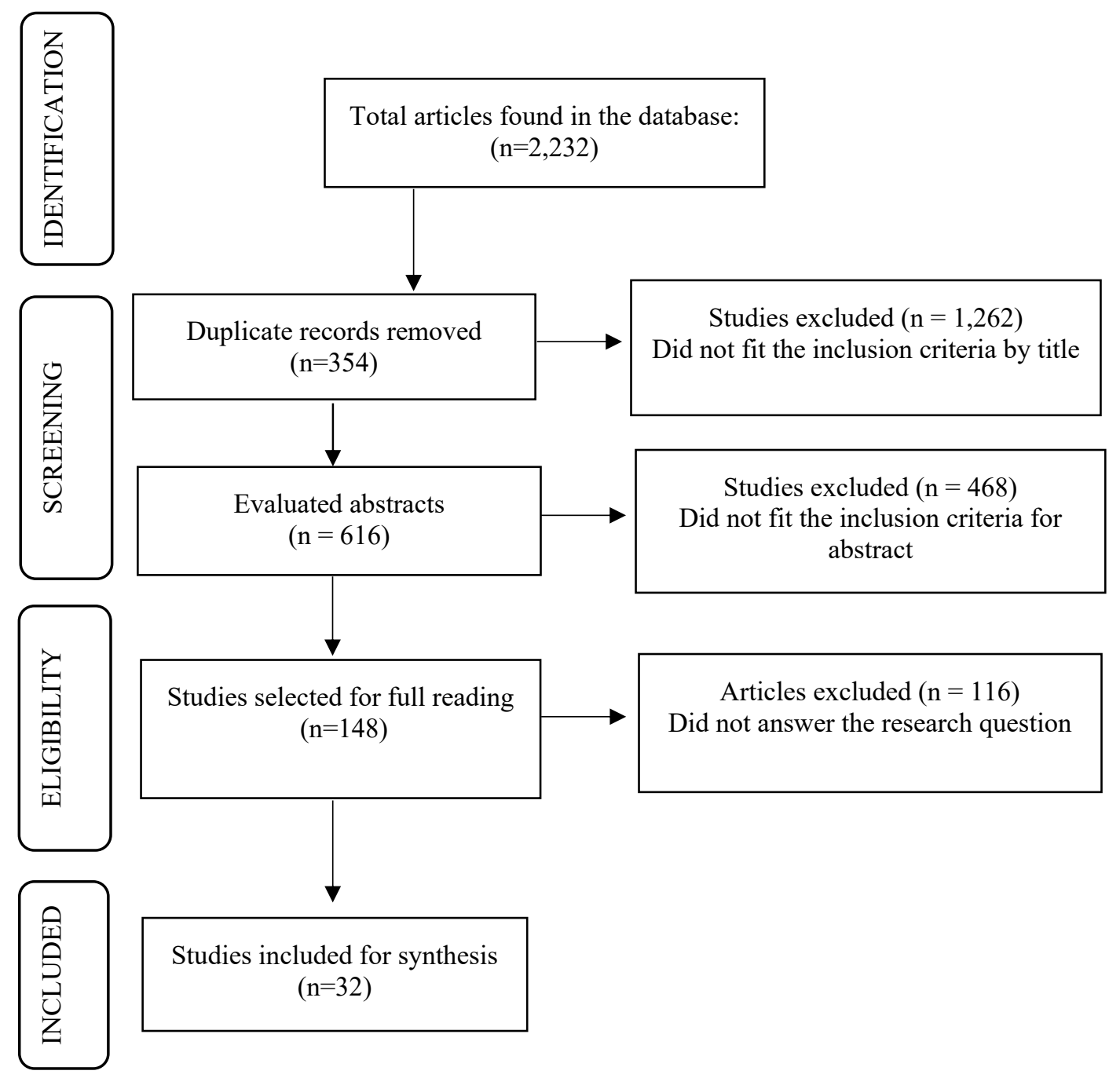

Figure 1 - Flowchart of the integrative literature review selection process Source: Adapted from PRISMA ${ }^{(13)}$.

of the populations, which can be explained by the diversity of locations and contexts being studied. The secondary sector workers stood out, accounting for 16 (50\%) of the sample, among them six (18.75\%) workers from the asbestos industries.

There was an increase in the number of publications between 2010 and 2014, representing 72\% of the sample. As for the carcinogenic substances with a causal relationship to lung cancer, asbestos was predominant in 12 (37.5\%) of the studies, followed by silica with nine (28.1\%) of the studies that comprised the sample.

The characteristics of the studies are shown in Chart 2 as follows: authorship, year and country; title objective and type of study; level of evidence; exposure and outcome.

\section{DISCUSSION}

It was observed that the scientific publications on the association between carcinogenic substances where the worker is exposed and lung cancer are predominantly international and developed in the Asian continent. It is inferred that this reality is due to the number of workers exposed to occupational carcinogens in China being similar to that of the developed countries, but with worse working conditions and exposure ${ }^{(16)}$.

In relation to the study participants, it was observed that the secondary sector workers were predominant in the sample, industries with 16 (50\%) of studies and two (6.2\%) from the civil construction. Six (18.7\%) studies were carried 


\begin{tabular}{|c|c|c|c|c|c|}
\hline $\begin{array}{l}\text { Author/ } \\
\text { Year/ } \\
\text { Country of } \\
\text { the study }\end{array}$ & Title & $\begin{array}{c}\text { Objective/Type of } \\
\text { Study } \\
\text { N= participants }\end{array}$ & $\begin{array}{l}\text { Level of } \\
\text { Evidence }\end{array}$ & Exposure & Outcome \\
\hline $\begin{array}{l}\text { Wu WT, } \\
\text { Lin YJ, Li Y, } \\
\text { Tsai PJ, } \\
\text { Yang CY, } \\
\text { Liou SH. } \\
\text { 2015, China }\end{array}$ & $\begin{array}{l}\text { Cancer } \\
\text { Attributable } \\
\text { to Asbestos } \\
\text { Exposure in } \\
\text { Shipbreaking } \\
\text { Workers: A } \\
\text { Matched-Cohort } \\
\text { Study }\end{array}$ & $\begin{array}{l}\text { To examine the } \\
\text { relationship between } \\
\text { cancer incidence } \\
\text { and asbestos } \\
\text { exposure among } \\
\text { former Taiwanese } \\
\text { ship workers. } \\
\text { Cohort study } \\
\mathrm{N}: 26,562\end{array}$ & IV & Asbestos & $\begin{array}{l}\text { The increase in the } \\
\text { incidence of lung cancer } \\
\text { is associated with the level } \\
\text { of exposure to asbestos } \\
\text { among naval workers. } \\
\text { Significant difference in } \\
\text { cancer compared to the } \\
\text { combined cohort. }\end{array}$ \\
\hline $\begin{array}{l}\text { Algranti E, } \\
\text { Buschinelli } \\
\text { JT, De } \\
\text { Capitani EM. } \\
\text { 2010, Brazil(16) }\end{array}$ & $\begin{array}{l}\text { Câncer } \\
\text { de pulmão } \\
\text { ocupacional }\end{array}$ & $\begin{array}{l}\text { To list the agents } \\
\text { recognized as } \\
\text { causes of lung } \\
\text { cancer and discuss } \\
\text { the contribution of } \\
\text { occupation to the } \\
\text { development of } \\
\text { the disease. } \\
\text { Review, descriptive. }\end{array}$ & $\mathrm{VI}$ & $\begin{array}{c}\text { Group } \\
\text { 1/IARC } \\
\text { carcinogenic } \\
\text { agents }\end{array}$ & $\begin{array}{l}\text { Publications on the } \\
\text { relationship between } \\
\text { occupation and cancer } \\
\text { in Brazil are restricted } \\
\text { to the area of public } \\
\text { health or occupational } \\
\text { pulmonology } \\
\text { services. There are few } \\
\text { epidemiological records of } \\
\text { occupational cancer that } \\
\text { allow for the detection } \\
\text { of risk situations and } \\
\text { their prevention. }\end{array}$ \\
\hline $\begin{array}{l}\text { Westberg } \mathrm{H}, \\
\text { Andersson } \mathrm{L}, \\
\text { Bryngelsson } \mathrm{L}, \\
\text { Ngo Y, } \\
\text { Ohlson CG. } \\
\text { 2013, } \\
\text { Sweden }^{(17)}\end{array}$ & $\begin{array}{l}\text { Cancer morbidity } \\
\text { and quartz } \\
\text { exposure } \\
\text { in Swedish } \\
\text { iron foundries }\end{array}$ & $\begin{array}{l}\text { To determine the } \\
\text { cancer morbidity } \\
\text { among Sweden } \\
\text { iron foundry } \\
\text { workers with exposure } \\
\text { to quartz. } \\
\text { Cohort study } \\
\mathrm{N}: 3,045\end{array}$ & IV & Quartz & $\begin{array}{l}\text { Overall cancer morbidity } \\
\text { was not increased among } \\
\text { the foundry workers, } \\
\text { but the incidence } \\
\text { of lung cancer was } \\
\text { significantly high. }\end{array}$ \\
\hline $\begin{array}{l}\text { Kishimoto T, } \\
\text { Gemba K, } \\
\text { Fujimoto N, } \\
\text { Onishi K, } \\
\text { Usami I, } \\
\text { Mizuhashi K, } \\
\text { Kimura K. } \\
\text { 2011, Japan }{ }^{(18)}\end{array}$ & $\begin{array}{l}\text { Clinical study of } \\
\text { asbestos-related } \\
\text { lung cancer in } \\
\text { Japan with special } \\
\text { reference to } \\
\text { occupational } \\
\text { history }\end{array}$ & $\begin{array}{l}\text { To investigate clinical } \\
\text { characteristics and } \\
\text { occupational history } \\
\text { for patents with } \\
\text { asbestos-related lung } \\
\text { cancer in Japan and } \\
\text { compare with patients } \\
\text { with non-asbestos- } \\
\text { related lung cancer. } \\
\text { Analytical, } \\
\text { cross-sectional study. } \\
\mathrm{N}: 152\end{array}$ & $\mathrm{VI}$ & Asbestos & $\begin{array}{l}\text { The risk for lung cancer } \\
\text { increased almost linearly } \\
\text { with the cumulative dose } \\
\text { of asbestos, and was } \\
\text { increased in the presence } \\
\text { of asbestosis. The } \\
\text { incidence of non-small } \\
\text { cell lung cancer for } \\
\text { patients with asbestosis } \\
\text { increased compared to } \\
\text { exposed patients, but } \\
\text { without asbestosis. }\end{array}$ \\
\hline
\end{tabular}

Chart 2 - Summary of the studies that comprised the sample 


\begin{tabular}{|c|c|c|c|c|c|}
\hline $\begin{array}{l}\text { Author/ } \\
\text { Year/ } \\
\text { Country of } \\
\text { the study }\end{array}$ & Title & $\begin{array}{c}\text { Objective/Type of } \\
\text { Study } \\
\text { N= participants }\end{array}$ & $\begin{array}{l}\text { Level of } \\
\text { Evidence }\end{array}$ & Exposure & Outcome \\
\hline $\begin{array}{l}\text { Hosgood HD, } \\
\text { Chapman RS, } \\
\text { Wei H, He X, } \\
\text { Tian L, Liu } \\
\text { LZ, et al. } \\
\text { 2012, China } \\
\text { (19) }\end{array}$ & $\begin{array}{l}\text { Coal mining is } \\
\text { associated with } \\
\text { lung cancer } \\
\text { risk in Xuanwei, } \\
\text { China }\end{array}$ & $\begin{array}{l}\text { To evaluate } \\
\text { the risk for lung } \\
\text { cancer in coal miners, } \\
\text { upon absence of } \\
\text { diesel exposure. } \\
\text { Case-control study. } \\
\text { N: } 520\end{array}$ & IV & Coal & $\begin{array}{l}\text { Increased risk for lung } \\
\text { cancer in coal } \\
\text { miners. There was a } \\
\text { relation between dose- } \\
\text { response and the lung } \\
\text { cancer risk with the years } \\
\text { working as a coal miner. }\end{array}$ \\
\hline $\begin{array}{l}\text { Sun Y, } \\
\text { Bochmann F, } \\
\text { Nold A, } \\
\text { Mattenklott M, } \\
\text { 2014, } \\
\text { Germany }^{(20)}\end{array}$ & $\begin{array}{l}\text { Diesel Exhaust } \\
\text { Exposure and } \\
\text { the Risk of } \\
\text { Lung Cancer: } \\
\text { A Review of the } \\
\text { Epidemiological } \\
\text { Evidence }\end{array}$ & $\begin{array}{l}\text { To evaluate the } \\
\text { association between } \\
\text { diesel exposure and } \\
\text { lung cancer risk. } \\
\text { Systematic review. }\end{array}$ & V & $\begin{array}{l}\text { Diesel } \\
\text { engine } \\
\text { exhaust }\end{array}$ & $\begin{array}{l}\text { The evaluated studies } \\
\text { do not indicate a clear } \\
\text { relationship between } \\
\text { the exposure to diesel } \\
\text { exhaust and lung cancer. }\end{array}$ \\
\hline $\begin{array}{l}\text { Lacasse } \\
\text { Y, Martin } \\
\text { S, Gagné } \\
\text { D, Lakhal L. } \\
\text { 2009, } \\
\text { Netherlands'(21) }\end{array}$ & $\begin{array}{l}\text { Dose-response } \\
\text { meta-analysis } \\
\text { of silica and } \\
\text { lung cancer }\end{array}$ & $\begin{array}{l}\text { To examine the } \\
\text { association between } \\
\text { occupational } \\
\text { exposure to silica } \\
\text { and lung cancer. } \\
\text { Systematic review } \\
\text { and meta-analysis. }\end{array}$ & V & Silica & $\begin{array}{l}\text { An increased risk for lung } \\
\text { cancer was found } \\
\text { with the increase } \\
\text { of the cumulative } \\
\text { exposure to silica. }\end{array}$ \\
\hline $\begin{array}{l}\text { Doi M, Hattori } \\
\text { N, } \\
\text { Yokoyama } \\
\text { UM, Onari Y, } \\
\text { Kanehara H, } \\
\text { Masuda K, } \\
\text { et al. } \\
\text { 2009, Japann }\end{array}$ & $\begin{array}{l}\text { Effect of Mustard } \\
\text { Gas Exposure } \\
\text { on Incidence of } \\
\text { Lung Cancer: A } \\
\text { Longitudinal Study }\end{array}$ & $\begin{array}{l}\text { To examine the } \\
\text { incidence of lung } \\
\text { cancer among } \\
\text { former mustard gas } \\
\text { factory workers. } \\
\text { Cohort study } \\
\mathrm{N}: 1,682\end{array}$ & IV & Mustard gas & $\begin{array}{l}\text { The relative risk in those } \\
\text { involved in making } \\
\text { mustard gas decreased } \\
\text { with increasing age at the } \\
\text { beginning of exposure. }\end{array}$ \\
\hline $\begin{array}{l}\text { Ahn Y-S, } \\
\text { Jeong KS. } \\
\text { 2014, Korea }\end{array}$ & $\begin{array}{l}\text { Epidemiologic } \\
\text { Characteristics } \\
\text { of Compensated } \\
\text { Occupational } \\
\text { Lung Cancers } \\
\text { among } \\
\text { Korean Workers }\end{array}$ & $\begin{array}{l}\text { To analyze the } \\
\text { characteristics of } \\
\text { occupational lung } \\
\text { cancers in workers } \\
\text { compensated by the } \\
\text { Industrial Accident } \\
\text { Compensation } \\
\text { Insurance Law } \\
\text { between } 1994 \\
\text { and } 2011 . \\
\text { Descriptive study. } \\
\text { N: } 179\end{array}$ & $\mathrm{Vl}$ & $\begin{array}{c}\text { Asbestos } \\
\text { Silica } \\
\text { Chromium } \\
\text { VI } \\
\text { Nickel } \\
\text { Diesel } \\
\text { engine } \\
\text { exhaust } \\
\text { PAHTar }\end{array}$ & $\begin{array}{l}\text { Asbestos was the main } \\
\text { exposure (48.6\%). There } \\
\text { was no significant } \\
\text { difference in the mean } \\
\text { duration of exposure or } \\
\text { latency with the agent } \\
\text { type. The main industries } \\
\text { were manufacturing, } \\
\text { construction and } \\
\text { transportation, and } \\
\text { maintenance and repair, } \\
\text { casting, welding, painting } \\
\text { and weaving occupations }\end{array}$ \\
\hline
\end{tabular}

Chart 2 - Cont. 


\begin{tabular}{|c|c|c|c|c|c|}
\hline $\begin{array}{l}\text { Author/ } \\
\text { Year/ } \\
\text { Country of } \\
\text { the study }\end{array}$ & Title & $\begin{array}{c}\text { Objective/Type of } \\
\text { Study } \\
\text { N= participants }\end{array}$ & $\begin{array}{l}\text { Level of } \\
\text { Evidence }\end{array}$ & Exposure & Outcome \\
\hline $\begin{array}{l}\text { Olsson AC, } \\
\text { Gustavsson P, } \\
\text { Kromhout H, } \\
\text { Peters S, } \\
\text { Vermeulen R, } \\
\text { Brüske I, et al. } \\
\text { 2010, } \\
\text { Multicentric (24) }\end{array}$ & $\begin{array}{l}\text { Exposure to } \\
\text { Diesel Motor } \\
\text { Exhaust and Lung } \\
\text { Cancer Risk in a } \\
\text { Pooled Analysis } \\
\text { from Case-Control } \\
\text { Studies in Europe } \\
\text { and Canada }\end{array}$ & $\begin{array}{l}\text { To investigate the risk } \\
\text { for lung } \\
\text { cancer associated } \\
\text { to occupational } \\
\text { exposure to diesel } \\
\text { engine exhaust. } \\
\text { Case-control study. } \\
\text { N:29,586 }\end{array}$ & IV & $\begin{array}{l}\text { Diesel } \\
\text { engine } \\
\text { exhaust }\end{array}$ & $\begin{array}{l}\text { Inconsistent association } \\
\text { between occupational } \\
\text { exposure to diesel } \\
\text { exhaust and the risk } \\
\text { for lung cancer. The } \\
\text { Odds Ratio (OR) was } \\
\text { significant for cumulative } \\
\text { diesel exposure in the } \\
\text { largest quartile. }\end{array}$ \\
\hline $\begin{array}{l}\text { LiuY, } \\
\text { Steenland K, } \\
\text { Rong Y, } \\
\text { Hnizdo E, } \\
\text { Huang X, } \\
\text { Zhang H, et } \\
\text { al. } \\
\text { 2013, China } \\
\text { (25) }\end{array}$ & $\begin{array}{l}\text { Exposure- } \\
\text { response } \\
\text { analysis and risk } \\
\text { assessment for } \\
\text { lung cancer in } \\
\text { relationship to } \\
\text { silica exposure: a } \\
44 \text { years cohort } \\
\text { study of } \\
34,018 \text { workers }\end{array}$ & $\begin{array}{l}\text { To investigate the risk } \\
\text { for developing lung } \\
\text { cancer in workers } \\
\text { exposed to silica. } \\
\text { Cohort study } \\
\text { N:34,018 }\end{array}$ & IV & Silica & $\begin{array}{l}\text { Silica is a human } \\
\text { carcinogen and current } \\
\text { exposure limits are } \\
\text { insufficient to protect } \\
\text { workers from the lung } \\
\text { cancer. Even with } 0.1 \mathrm{mg} / \\
\mathrm{m}^{3} \text { of silica exposure, the } \\
\text { estimated risk along life } \\
\text { was } 0.51 \% \text {. }\end{array}$ \\
\hline $\begin{array}{l}\text { Lin CK, } \\
\text { Chang AA, } \\
\text { Wang JD, } \\
\text { Lee LJ. } \\
\text { 2015, China } \\
\end{array}$ & $\begin{array}{l}\text { Increased } \\
\text { Standardised } \\
\text { Incidence Ratio of } \\
\text { Malignant Pleural } \\
\text { Mesothelioma } \\
\text { in Taiwanese } \\
\text { Asbestos Workers: } \\
\text { A 29-Year } \\
\text { Retrospective } \\
\text { Cohort Study }\end{array}$ & $\begin{array}{l}\text { To determine } \\
\text { the incidence rate of } \\
\text { malignant pleura } \\
\text { mesothelioma (MPM) } \\
\text { in workers } \\
\text { exposed to asbestos } \\
\text { in Taiwan. } \\
\text { Cohort study } \\
\mathrm{N}: 160,640\end{array}$ & IV & Asbestos & $\begin{array}{l}\text { Association between } \\
\text { occupational exposure } \\
\text { to asbestos and Pleural } \\
\text { Malignant Mesothelioma } \\
\text { (PMM). The greatest risk } \\
\text { was found among male } \\
\text { workers employed before } \\
1979 \text { and working for } \\
\text { more than } 20 \text { years in } \\
\text { asbestos factories. }\end{array}$ \\
\hline $\begin{array}{l}\text { Garshick } \\
\text { E, Laden F, } \\
\text { Hart JE, Davis } \\
\text { ME, Eisen EA, } \\
\text { Smith TJ. } \\
\text { 2012, USA } \\
\end{array}$ & $\begin{array}{l}\text { Lung Cancer } \\
\text { and Elemental } \\
\text { Carbon Exposure } \\
\text { in Trucking } \\
\text { Industry Workers }\end{array}$ & $\begin{array}{l}\text { To evaluate the risk of } \\
\text { mortality due to } \\
\text { lung cancer among } \\
\text { workers in the } \\
\text { truck industry of } \\
\text { the USA } \\
\text { Cohort study } \\
\text { N:31,135 }\end{array}$ & IV & $\begin{array}{c}\text { Elemental } \\
\text { carbon }\end{array}$ & $\begin{array}{l}\text { The mortality by lung } \\
\text { cancer in } \\
\text { workers of the } \\
\text { truck industry increased } \\
\text { in association with the } \\
\text { cumulative exposure } \\
\text { to elemental } \\
\text { carbon. }\end{array}$ \\
\hline
\end{tabular}

Chart 2 - Cont. 


\begin{tabular}{|c|c|c|c|c|c|}
\hline $\begin{array}{l}\text { Author/ } \\
\text { Year/ } \\
\text { Country of } \\
\text { the study }\end{array}$ & Title & $\begin{array}{c}\text { Objective/Type of } \\
\text { Study } \\
N=\text { participants }\end{array}$ & $\begin{array}{l}\text { Level of } \\
\text { Evidence }\end{array}$ & Exposure & Outcome \\
\hline $\begin{array}{l}\text { Consonni D, } \\
\text { De Matteis S, } \\
\text { Lubin JH, } \\
\text { Wacholder S, } \\
\text { Tucker M, } \\
\text { Pesatori AC, } \\
\text { et al. } \\
2010 \text {, Italy }\end{array}$ & $\begin{array}{l}\text { Lung Cancer and } \\
\text { Occupation in a } \\
\text { Population-based } \\
\text { Case-Control Study }\end{array}$ & $\begin{array}{l}\text { To examine the } \\
\text { relationship between } \\
\text { the occupation type } \\
\text { and lung cancer. } \\
\text { Case-control study } \\
\mathrm{N}: 4,220\end{array}$ & IV & $\begin{array}{l}\text { Only } \\
\text { occupations } \\
\text { were defined }\end{array}$ & $\begin{array}{l}\text { Excessive risks were } \\
\text { found in metal workers, } \\
\text { barbers and hairdressers, } \\
\text { and vehicle drivers. } \\
\text { Exposure to occupational } \\
\text { carcinogens is a } \\
\text { determining factor in lung } \\
\text { cancer occurrence. }\end{array}$ \\
\hline $\begin{array}{l}\text { Bugge MD, } \\
\text { Kjærheim K, } \\
\text { Foreland S, } \\
\text { Eduard W, } \\
\text { Kjuus H. } \\
2012, \\
\text { Norway }\end{array}$ & $\begin{array}{l}\text { Lung cancer } \\
\text { incidence among } \\
\text { Norwegian } \\
\text { silicon carbide } \\
\text { industry workers: } \\
\text { associations } \\
\text { with particulate } \\
\text { exposure factors }\end{array}$ & $\begin{array}{l}\text { To examine the } \\
\text { relationship between } \\
\text { exposure to silicon } \\
\text { carbide (SiC) and lung } \\
\text { cancer in workers } \\
\text { from a Norwegian } \\
\text { SiC industry. } \\
\text { Cohort study } \\
\mathrm{N}: 1,687\end{array}$ & IV & $\begin{array}{l}\text { Silicon } \\
\text { carbide } \\
\text { (SiC) }\end{array}$ & $\begin{array}{l}2 \text { to } 3 \text { times higher risk for } \\
\text { lung cancer associated } \\
\text { with a higher level of } \\
\text { cumulative exposure to } \\
\text { SiC particles and fibers } \\
\text { among workers in the SiC } \\
\text { industry compared to the } \\
\text { general male population. }\end{array}$ \\
\hline $\begin{array}{l}\text { Yano E, Wang } \\
\text { X, } \\
\text { Wang M, } \\
\text { Qiu H, } \\
\text { Wang Z. } \\
\text { 2010, } \\
\text { China } \\
(30)\end{array}$ & $\begin{array}{l}\text { Lung cancer } \\
\text { mortality from } \\
\text { exposure to } \\
\text { chrysotile } \\
\text { asbestos and } \\
\text { smoking: a case- } \\
\text { control study } \\
\text { within a cohort } \\
\text { in China }\end{array}$ & $\begin{array}{l}\text { To analyze the } \\
\text { association between } \\
\text { the exposure to } \\
\text { chrysotile asbestos } \\
\text { and the risk } \\
\text { for lung cancer and } \\
\text { demonstrate the } \\
\text { combined effect of } \\
\text { smoking and } \\
\text { the exposure to } \\
\text { this substance. } \\
\text { Case-control study. } \\
\mathrm{N}: 1,139\end{array}$ & IV & Asbestos & $\begin{array}{l}\text { The risk for lung cancer } \\
\text { in the group with high } \\
\text { exposure to asbestos was } \\
3 \text { times higher than in the } \\
\text { reference group. There } \\
\text { was a strong association } \\
\text { between exposure } \\
\text { to chrysotile } \\
\text { asbestos and the risk } \\
\text { for lung cancer and, } \\
\text { increased risk in the } \\
\text { interaction with smoking. }\end{array}$ \\
\hline $\begin{array}{l}\text { Consonni D, } \\
\text { De Matteis S, } \\
\text { Pesatori AC, } \\
\text { Bertazzi PA, } \\
\text { Olsson AC, } \\
\text { Kromhout H, } \\
\text { et al. } \\
\text { 2015, } \\
\text { Multicentric }^{(31)}\end{array}$ & $\begin{array}{l}\text { Lung cancer risk } \\
\text { among bricklayers } \\
\text { in a pooled } \\
\text { analysis of } \\
\text { case-control } \\
\text { studies }\end{array}$ & $\begin{array}{l}\text { To examine the risk for } \\
\text { lung cancer among } \\
\text { construction workers } \\
\text { and the joint effects } \\
\text { of occupational } \\
\text { carcinogens. } \\
\text { Case-control } \\
\text { study. } \\
\mathrm{N}: 34,139\end{array}$ & IV & Silica & $\begin{array}{l}\text { There was an increased } \\
\text { risk for lung cancer } \\
\text { adjusted to smoking for } \\
\text { bricklayers and a positive } \\
\text { association with working } \\
\text { time. The association was } \\
\text { greater in the exposure to } \\
\text { crystalline silica. }\end{array}$ \\
\hline
\end{tabular}

Chart 2 - Cont. 


\begin{tabular}{|c|c|c|c|c|c|}
\hline $\begin{array}{l}\text { Author/ } \\
\text { Year/ } \\
\text { Country of } \\
\text { the study }\end{array}$ & Title & $\begin{array}{l}\text { Objective/Type of } \\
\text { Study } \\
\text { N= participants }\end{array}$ & $\begin{array}{l}\text { Level of } \\
\text { Evidence }\end{array}$ & Exposure & Outcome \\
\hline $\begin{array}{l}\text { Brenner DR, } \\
\text { Hung RJ, Tsao } \\
\text { MS, } \\
\text { Shepherd FA, } \\
\text { Johnston MR, } \\
\text { Narod S, et al. } \\
\text { 2010, } \\
\text { Canada }^{(32)}\end{array}$ & $\begin{array}{l}\text { Lung cancer risk } \\
\text { in never-smokers: } \\
\text { a population- } \\
\text { based case- } \\
\text { control study of } \\
\text { epidemiologic } \\
\text { risk factors }\end{array}$ & $\begin{array}{l}\text { To evaluate potential } \\
\text { risk factors } \\
\text { for lung cancer. } \\
\text { Case-control study. } \\
\text { N: } 948\end{array}$ & IV & $\begin{array}{l}\text { Smoking } \\
\text { Solvents } \\
\text { and paints, } \\
\text { Solder } \\
\text { Soot or } \\
\text { exhaustion }\end{array}$ & $\begin{array}{l}\text { Association of increased } \\
\text { risk for lung cancer in } \\
\text { non-smokers exposed to } \\
\text { occupational carcinogens, } \\
\text { family history of cancer } \\
\text { with recent onset } \\
\text { and past history of } \\
\text { respiratory diseases. }\end{array}$ \\
\hline $\begin{array}{l}\text { Ghanei M, } \\
\text { Harandi AA. } \\
\text { 2011, USA }\end{array}$ & $\begin{array}{l}\text { Lung } \\
\text { Carcinogenicity of } \\
\text { Sulfur Mustard }\end{array}$ & $\begin{array}{l}\text { To review all } \\
\text { published documents } \\
\text { on the mustard lung } \\
\text { carcinogenicity after } \\
\text { chronic exposure. } \\
\text { Review, descriptive. }\end{array}$ & VI & Mustard gas & $\begin{array}{l}\text { Mustard gas has been } \\
\text { shown to cause lung } \\
\text { cancer after chronic } \\
\text { (long-term) exposure. } \\
\text { It was not possible to } \\
\text { conclude whether the } \\
\text { single exposure to high } \\
\text { doses of the gas causes } \\
\text { lung cancer. }\end{array}$ \\
\hline $\begin{array}{l}\text { Wang } X, \\
\text { Lin } S, \\
\text { Yu IT, } \\
\text { Tse L, et al. } \\
\text { 2011, } \\
\text { China }^{(34)}\end{array}$ & $\begin{array}{l}\text { Mortality in a } \\
\text { Chinese chrysotile } \\
\text { miner cohort }\end{array}$ & $\begin{array}{l}\text { To evaluate the } \\
\text { association between } \\
\text { exposure to asbestos } \\
\text { and mortality due } \\
\text { to specific causes } \\
\text { in workers at } \\
\text { asbestos mine. } \\
\text { Cohort study } \\
\text { N:1,539 }\end{array}$ & IV & Asbestos & $\begin{array}{l}\text { The most prominent } \\
\text { death causes were lung } \\
\text { cancer and non-malignant } \\
\text { respiratory diseases in } \\
\text { workers who were directly } \\
\text { involved in chrysotile } \\
\text { asbestos mining. }\end{array}$ \\
\hline $\begin{array}{l}\text { Poinen- } \\
\text { Rughooputh } \\
\text { S, } \\
\text { Rughooputh } \\
\text { MS, Guo Y, } \\
\text { Rong Y, } \\
\text { Chen W. } \\
\text { 2016, China }\end{array}$ & $\begin{array}{l}\text { Occupational } \\
\text { exposure to silica } \\
\text { dust and risk } \\
\text { of lung cancer: } \\
\text { an updated } \\
\text { meta-analysis } \\
\text { of epidemiological } \\
\text { studies }\end{array}$ & $\begin{array}{l}\text { To review the } \\
\text { epidemiological } \\
\text { evidences on the } \\
\text { relationship between } \\
\text { occupational } \\
\text { exposure to silica } \\
\text { and the risk for } \\
\text { lung cancer. } \\
\text { Systematic review } \\
\text { and Meta-analysis. }\end{array}$ & V & Silica & $\begin{array}{l}\text { Association between } \\
\text { crystalline silica and } \\
\text { lung cancer and an } \\
\text { exposure-response } \\
\text { relationship between } \\
\text { them, with a high degree } \\
\text { of heterogeneity. The risk } \\
\text { is greater in the presence } \\
\text { of silicosis and in the } \\
\text { mining industry. }\end{array}$ \\
\hline $\begin{array}{l}\text { Chang CJ, } \\
\text { TuYK, } \\
\text { Chen PC, } \\
\text { Yang HY. } \\
\text { 2017, China(36) }\end{array}$ & $\begin{array}{l}\text { Occupational } \\
\text { Exposure to Talc } \\
\text { Increases the Risk } \\
\text { of Lung Cancer: } \\
\text { A Meta-Analysis } \\
\text { of Occupational } \\
\text { Cohort Studies }\end{array}$ & $\begin{array}{l}\text { To evaluate how } \\
\text { occupational } \\
\text { exposure to inhaled } \\
\text { talc affects the risk for } \\
\text { lung cancer. } \\
\text { Systematic Review } \\
\text { and Meta-analysis. }\end{array}$ & V & Talc & $\begin{array}{l}\text { Positive association } \\
\text { between exposure to talc } \\
\text { and lung cancer. }\end{array}$ \\
\hline
\end{tabular}

Chart 2 - Cont. 


\begin{tabular}{|c|c|c|c|c|c|}
\hline $\begin{array}{l}\text { Author/ } \\
\text { Year/ } \\
\text { Country of } \\
\text { the study }\end{array}$ & Title & $\begin{array}{c}\text { Objective/Type of } \\
\text { Study } \\
\mathrm{N}=\text { participants }\end{array}$ & $\begin{array}{l}\text { Level of } \\
\text { Evidence }\end{array}$ & Exposure & Outcome \\
\hline $\begin{array}{l}\text { Ferrante D, } \\
\text { Mirabelli D, } \\
\text { Tunesi S, } \\
\text { Terracini B, } \\
\text { Magnani C. } \\
\text { 2016, Italy }{ }^{(37)}\end{array}$ & $\begin{array}{l}\text { Pleural } \\
\text { mesothelioma } \\
\text { and occupational } \\
\text { and non- } \\
\text { occupational } \\
\text { asbestos } \\
\text { exposure: a case- } \\
\text { control study } \\
\text { with quantitative } \\
\text { risk assessment }\end{array}$ & $\begin{array}{l}\text { To quantify the } \\
\text { association between } \\
\text { pleural malignant } \\
\text { mesothelioma and } \\
\text { cumulative exposure } \\
\text { to asbestos. } \\
\text { Case-control study. } \\
\text { N: } 548\end{array}$ & IV & Asbestos & $\begin{array}{l}\text { Relationship between } \\
\text { the incidence of pleural } \\
\text { malignant mesothelioma } \\
\text { and cumulative exposure } \\
\text { to asbestos, even at low } \\
\text { exposure levels. }\end{array}$ \\
\hline $\begin{array}{l}\text { Swiatkowska } \\
\text { B, Szubert } \\
\text { Z, Sobala W, } \\
\text { Szeszenia- } \\
\text { Dabbrowska } \\
\text { N. 2015, } \\
\text { Poland } \\
\end{array}$ & $\begin{array}{l}\text { Predictors of } \\
\text { lung cancer } \\
\text { among former } \\
\text { asbestos-exposed } \\
\text { workers }\end{array}$ & $\begin{array}{l}\text { To evaluate the } \\
\text { influence of smoking } \\
\text { and factors related } \\
\text { to occupational } \\
\text { exposure on the } \\
\text { risk of lung cancer } \\
\text { incidence in workers } \\
\text { exposed to asbestos. } \\
\text { Case-control study. } \\
\mathrm{N}: 7,374\end{array}$ & IV & Asbestos & $\begin{array}{l}\text { The risk for lung cancer is } \\
\text { associated with exposure } \\
\text { to asbestos and increases } \\
\text { with cumulative exposure. } \\
\text { The risk continued } \\
\text { to increase until } 30 \\
\text { years after the end of } \\
\text { asbestos exposure. }\end{array}$ \\
\hline $\begin{array}{l}\text { Clin B, } \\
\text { Andujar P, } \\
\text { AbdAl Samad } \\
\text { I, Azpitarte } \\
\text { C, Billon- } \\
\text { Galland MA, } \\
\text { et al. } \\
\text { 2012, } \\
\text { France } \\
\text { (39) }\end{array}$ & $\begin{array}{l}\text { Pulmonary } \\
\text { carcinoid } \\
\text { tumors and } \\
\text { asbestos exposure }\end{array}$ & $\begin{array}{l}\text { To analyze the } \\
\text { relationship between } \\
\text { exposure to asbestos } \\
\text { and pulmonary } \\
\text { carcinoid tumors. } \\
\text { Retrospective, } \\
\text { case-control. } \\
\text { N: } 84\end{array}$ & IV & Asbestos & $\begin{array}{l}\text { There is a relationship } \\
\text { between occupational } \\
\text { exposure to asbestos and } \\
\text { certain lung carcinoid } \\
\text { tumors. Cumulative } \\
\text { exposure to asbestos } \\
\text { was greater in cases with } \\
\text { a carcinoid tumor and } \\
\text { older than } 40 \text { years than in } \\
\text { the controls. }\end{array}$ \\
\hline $\begin{array}{l}\text { Zurbriggen R, } \\
\text { Capone L. } \\
\text { 2013, } \\
\text { Argentina }^{(40)}\end{array}$ & $\begin{array}{l}\text { Enfermedad } \\
\text { pulmonar por } \\
\text { amianto en } \\
\text { trabajadores } \\
\text { de acería }\end{array}$ & $\begin{array}{l}\text { To describe the } \\
\text { general, clinical, } \\
\text { and radiological } \\
\text { characteristics of } \\
\text { patients exposed to } \\
\text { chrysotile asbestos in } \\
\text { the steel industry. } \\
\text { Descriptive study } \\
\mathrm{N}: 27\end{array}$ & $\mathrm{Vl}$ & Asbestos & $\begin{array}{l}\text { Steel kiln workers had a } \\
\text { high degree of exposure } \\
\text { to chrysotile asbestos, } \\
\text { in its use as insulation. } \\
\text { Presence of benign pleural } \\
\text { lesions and asbestosis, and } \\
18.5 \% \text { with mesothelioma } \\
\text { and lung cancer. }\end{array}$ \\
\hline
\end{tabular}

Chart 2 - Cont. 


\begin{tabular}{|c|c|c|c|c|c|}
\hline $\begin{array}{l}\text { Author/ } \\
\text { Year/ } \\
\text { Country of } \\
\text { the study }\end{array}$ & Title & $\begin{array}{c}\text { Objective/Type of } \\
\text { Study } \\
\mathrm{N}=\text { participants }\end{array}$ & $\begin{array}{l}\text { Level of } \\
\text { Evidence }\end{array}$ & Exposure & Outcome \\
\hline $\begin{array}{l}\text { Sogl M, } \\
\text { Taeger D, } \\
\text { Pallapies } \\
\text { D, Bruning } \\
\text { T, Dufey F, } \\
\text { Schnelzer M, } \\
\text { et al. } \\
\text { 2012, } \\
\text { Germany }\end{array}$ & $\begin{array}{l}\text { Quantitative } \\
\text { relationship } \\
\text { between silica } \\
\text { exposure and } \\
\text { lung cancer } \\
\text { mortality in } \\
\text { German uranium } \\
\text { miners, 1946-2003 }\end{array}$ & $\begin{array}{l}\text { To investigate the } \\
\text { exposure-response } \\
\text { relationship between } \\
\text { crystalline silica } \\
\text { exposure and lung } \\
\text { cancer mortality and } \\
\text { the combined effect } \\
\text { of silica and radon. } \\
\text { Cohort study } \\
\text { N:58,987 }\end{array}$ & IV & Silica & $\begin{array}{l}\text { High risk for lung cancer } \\
\text { in accumulated silica } \\
\text { exposures. The findings } \\
\text { support the IARC's } \\
\text { assessment to classify } \\
\text { silica as a carcinogen for } \\
\text { lung cancer in humans. }\end{array}$ \\
\hline $\begin{array}{l}\text { Tse LA, } \\
\text { Yu IT, Au JSK, } \\
\text { Qiu H, } \\
\text { Wang X. } \\
\text { 2011, China( }{ }^{(42)}\end{array}$ & $\begin{array}{l}\text { Silica dust, diesel } \\
\text { exhaust, and } \\
\text { painting work are } \\
\text { the significant } \\
\text { occupational } \\
\text { risk factors for } \\
\text { lung cancer in } \\
\text { nonsmoking } \\
\text { Chinese men }\end{array}$ & $\begin{array}{l}\text { To explore the } \\
\text { associations between } \\
\text { occupational } \\
\text { exposures and } \\
\text { lung cancer in } \\
\text { non-smoking men } \\
\text { throughout their lives. } \\
\text { Case-control study. } \\
\text { N: } 668\end{array}$ & IV & $\begin{array}{l}\text { Silica } \\
\text { Diesel } \\
\text { engine } \\
\text { exhaust } \\
\text { Spray paint }\end{array}$ & $\begin{array}{l}\text { Construction workers and } \\
\text { those who had already } \\
\text { been occupationally } \\
\text { exposed to silica dust, } \\
\text { diesel exhaust and spray } \\
\text { paint were associated } \\
\text { with an increased risk for } \\
\text { lung cancer, regardless } \\
\text { of smoking. }\end{array}$ \\
\hline $\begin{array}{l}\text { Steenland K, } \\
\text { Ward E. } \\
\text { 2014, USA } \\
\end{array}$ & $\begin{array}{l}\text { Silica: A } \\
\text { Lung Carcinogen }\end{array}$ & $\begin{array}{l}\text { To highlight the } \\
\text { effects of silica on } \\
\text { health and the } \\
\text { prevention of disease } \\
\text { and death from } \\
\text { exposure to silica } \\
\text { at work. } \\
\text { Review, descriptive. }\end{array}$ & $\mathrm{VI}$ & Silica & $\begin{array}{l}\text { Exposure to silica increases } \\
\text { the risk for lung cancer. } \\
\text { Compared to smoking } \\
\text { or asbestos, the risk for } \\
\text { lung cancer is lower, } \\
\text { making it more difficult } \\
\text { to differentiate the } \\
\text { contributions of exposure } \\
\text { to silica, silicosis and } \\
\text { smoking to cancer. }\end{array}$ \\
\hline $\begin{array}{l}\text { Silverman } \\
\text { DT, Samanic } \\
\text { CM, Lubin } \\
\text { JH, Blair AE, } \\
\text { Stewart PA, } \\
\text { Vermeulen R, } \\
\text { et al. } \\
2012, \\
\text { Canada }\end{array}$ & $\begin{array}{l}\text { The Diesel } \\
\text { Exhaust in Miners } \\
\text { Study: A Nested } \\
\text { Case - Control } \\
\text { Study of Lung } \\
\text { Cancer and } \\
\text { Diesel Exhaust }\end{array}$ & $\begin{array}{l}\text { To evaluate the } \\
\text { relationship between } \\
\text { quantitative estimates } \\
\text { of diesel exhaust } \\
\text { exposure and lung } \\
\text { cancer mortality. } \\
\text { Case-control study } \\
\text { N: } 864\end{array}$ & IV & $\begin{array}{l}\text { Diesel } \\
\text { engine } \\
\text { exhaust }\end{array}$ & $\begin{array}{l}\text { The results provide } \\
\text { evidence that exposure } \\
\text { to diesel can cause lung } \\
\text { cancer in humans and } \\
\text { represent a potential } \\
\text { public health burden. }\end{array}$ \\
\hline
\end{tabular}

Chart 2 - Cont. 


\begin{tabular}{|c|c|c|c|c|c|}
\hline $\begin{array}{l}\text { Author/ } \\
\text { Year/ } \\
\text { Country of } \\
\text { the study }\end{array}$ & Title & $\begin{array}{c}\text { Objective/Type of } \\
\text { Study } \\
\mathrm{N}=\text { participants }\end{array}$ & $\begin{array}{l}\text { Level of } \\
\text { Evidence }\end{array}$ & Exposure & Outcome \\
\hline $\begin{array}{l}\text { Järvholm B, } \\
\text { Åstrom E. } \\
\text { 2014, } \\
\text { Sweden(45) }\end{array}$ & $\begin{array}{l}\text { The Risk of } \\
\text { Lung Cancer } \\
\text { After Cessation } \\
\text { of Asbestos } \\
\text { Exposure in } \\
\text { Construction } \\
\text { Workers Using } \\
\text { Pleural Malignant } \\
\text { Mesothelioma } \\
\text { as a Marker } \\
\text { of Exposure }\end{array}$ & $\begin{array}{l}\text { To investigate the } \\
\text { risk for lung cancer } \\
\text { after ending the } \\
\text { asbestos exposure } \\
\text { and compare the risk } \\
\text { for lung cancer in } \\
\text { construction workers } \\
\text { exposed to asbestos } \\
\text { before and after } \\
\text { the exposure. } \\
\text { Cohort study } \\
\mathrm{N}: 189,896\end{array}$ & IV & Asbestos & $\begin{array}{l}\text { The risk for lung cancer } \\
\text { was similar among } \\
\text { workers with high and low } \\
\text { exposure } 20 \text { years after the } \\
\text { last exposure. The same } \\
\text { is not true for the risk for } \\
\text { mesothelioma, which is } \\
\text { greater } 20 \text { years after the } \\
\text { last exposure. }\end{array}$ \\
\hline $\begin{array}{l}\text { De Matteis } \\
\text { S, Conssoni } \\
\text { D, Lubin } \\
\text { JH, Tucker } \\
\text { M, Peters S, } \\
\text { Vermeulen } \\
\text { RCh, et al. } \\
2012 \text {, } \\
\text { Italy }\end{array}$ & $\begin{array}{l}\text { Impact of } \\
\text { occupational } \\
\text { carcinogens } \\
\text { on lung cancer } \\
\text { risk in on } \\
\text { general population }\end{array}$ & $\begin{array}{l}\text { To quantify lung } \\
\text { cancer burden } \\
\text { attributable to } \\
\text { occupational } \\
\text { carcinogens in a } \\
\text { general population. } \\
\text { Case-control study } \\
\text { N:4,220 }\end{array}$ & IV & $\begin{array}{l}\text { Asbestos } \\
\text { Silica } \\
\text { Nickel- } \\
\text { chromium }\end{array}$ & $\begin{array}{l}\text { Men showed an increased } \\
\text { lung cancer risk even } \\
\text { at low exposure to } \\
\text { carcinogens The risk is } \\
\text { great to asbestos (OR: 1.76; } \\
\text { IC 95\%). The risk increased } \\
\text { with exposure level. }\end{array}$ \\
\hline
\end{tabular}

Chart 2 - Cont

Source: Research data, 2018

out with workers in the primary sector (mining) and only three (9.3\%) in the tertiary sector (transport and painting). The occurrence of more studies related to the secondary sector may be due to a higher concentration of carcinogenic agents in this sector and related cases of lung cancer, and also by the risk of activities concentrated there and a greater contingent of exposed workers.

A study carried out in 2012 showed that lung cancer mortality among workers in the truck industry increased in association with cumulative exposure to elemental carbon. Until the year 2000, of the total of 4,306 deaths, 779 were caused by lung cancer ${ }^{(27)}$. In a study published in 2015, there was an increased risk for smoking-adjusted lung cancer in construction workers, with a clear positive association with working time. The association was plausible given the potential for exposure to various carcinogens, especially crystalline silica and, to a lesser extent, asbestos ${ }^{(31)}$.

Male workers make up the majority of the population in the studies analyzed. This event is due to the fact that men occupy most of the positions in the industries that use such carcinogenic substances. A 2015 study exemplifies this predominance, where 4,424 workers in a harbor industry,3,732 were men and only 695 were women ${ }^{(15)}$. Another example was described in 2010, which investigated the risk for lung cancer associated with occupational exposure to exhaust from the diesel engine, and obtained $81 \%$ of men in its sample ${ }^{(24)}$. In 2015, a study was carried out where there were a total of 160,640 workers in asbestos-related factories was available for study, and three quarters of these were male ${ }^{(26)}$.

The prevalent substance in the sample of this research was asbestos in 12 (37.5\%) studies related to this exposure ${ }^{(15,18,23,26,30,34,37-40,45-46)}$ and their association with lung cancer. Many countries, including Japan, have banned the production and use of any type of asbestos, while other countries, including China, continue to produce and use large quantities of chrysotile asbestos in construction materials ${ }^{(30)}$.

The five largest asbestos producers in the world are the following: Russia, China, Brazil, Kazakhstan, and Canada. The world has about 200 million tons of asbestos from natural resources. Although Brazil is the third largest producer 
(250,000 tons/year) of asbestos in the world, the national anti-asbestos campaign has favored the decline in its use, however the surplus, which reaches $65 \%$, has been exported mainly to countries in Asia and Latin America. In Brazil, most of the commercialized asbestos pertain to the chrysotile or white asbestos type, with more than 90\%being consumed by the fiber-cement and textile industries and 10\% in friction materials (auto parts) and chemical-plastic industries ${ }^{(47-48)}$.

In November 2017, the Federal Supreme Court (Supremo Tribunal Federal, STF) voted in favor of a total ban on asbestos in Brazil. Therefore, the extraction, industrialization, and commercialization of any product containing chrysotile asbestos in its composition in the national territory was prohibited, and both the Congress and the states will not be able to pass laws to authorize its use ${ }^{(49)}$. However, the summary has not yet been published, and pro-asbestos movements are fighting for the return of extraction.

Exposure to asbestos is an established risk factor for the development of lung cancer. It was found in several selected studies that the greater the exposure is, the more eminent the summary risk becomes more eminent ${ }^{\left({ }^{(31)}\right.}$. There is an increase in the risk for lung cancer almost linearly with the cumulative dose of asbestos ${ }^{(3)}$; however, a number of studies have shown that when exposure is reduced, the risk decreases proportionally ${ }^{(3,31)}$.

The development of lung cancer also varied between occupational groups depending on the degree of exposure to asbestos. The survey showed six studies directly related to workers in industries associated with Asbestos $(18,26,30,32,38-39)$.

In addition, it is necessary to emphasize that the association between smoking and exposure to asbestos becomes an extremely dangerous combination. Regarding smoking in a study with 154 individuals, only 15 patients (10\%) were non-smokers and 134 were smokers or ex-smokers. Seventy-one patients (47\%) were classified as heavy smokers. Lung cancer can occur in non-smokers exposed to asbestos; however, the risk is increased by smoking, and the increased risk for lung cancer remains up to 20 years after smoking cessation ${ }^{(18)}$.

Although asbestos production and use have been banned in certain countries, cases of lung cancer continue to arise due to the latency period that can reach 50 years after the end of the exposure. One rate of this percentage refers to mesothelioma, a rare and lethal cancer, which is caused by exposure to asbestos. In 2015 the association between occupational exposure to asbestos and pleural malignant mesothelioma (PMM) was proven. The highest risk for MPM was found among workers in the male asbestos industries ${ }^{(26)}$.

The second most evidenced substance associated with lung cancer in the sample of this research was silica in nine
(28.1\%) of the studies $(21,23,25,31,35,41-43,46)$. Recent reports have indicated that more than 1.7 million workers in the United States, more than 2 million in Europe and more than 23 million in China have been occupationally exposed to crystalline silica dust ${ }^{(26)}$. Silica is a proven lung carcinogen. This increased risk is particularly apparent when the cumulative exposure to silica is beyond the recommended limit concentration for a prolonged period of exposure $e^{(21,46)}$.

The diesel engine exhaust was recurrent in four (12.5\%) of the studies ${ }^{(20,24,42,44)}$, followed by the mustard gas indicated in $6.2 \%$ of the sample ${ }^{(22,33)}$. The other substances were the following: Quartz, Coal, Nickel, Chromium VI, Elementary Carbon, Silicon Carbide, Talc, and Spray Paint. All of them with high, medium, or low risk for lung cancer, depending on exposure conditions.

Several types of carcinogenic substances have been described in the studies, since in the occupational environment there are several significant potential sources of risk for lung cancer, including exposure to solvents, paints or thinners, welding and smoke equipment, soot or exhaust, as well as asbestos, and silica, among other carcinogens.

\section{GINAL CONSIDERATIONS}

The association between occupational exposure and the risk for lung cancer was characterized in this research by the substantial scientific evidence from the studies described that confirm this association. However, the production of knowledge and the debate on the consequences that carcinogenic substances cause on the worker's health must be expanded to create measures to monitor the worker's health and safety.

In Brazil, cases of illness and death related to exposure to carcinogenic substances at work must compulsorily be notified in the Brazilian Disease Information and Notification System (Sistema de Informações e Agravos de Notificação, SINAN) and monitored by the epidemiological health services.

With asbestos as the most recurrent substance in the sample, the need for stricter control and surveillance is stated, since Brazil ranks third in the world asbestos producer ranking and even though its ban had occurred in late 2017, and still in court there is a proposal for the continuation of extraction, and it is estimated that the increase in cases related to this substance will reach its peak in 2021 and perpetuating for another 40 to 50 years.

The need to expand the national scientific production on the subject is emphasized, given that only one Brazilian publication made up the sample of this research. There is a lack of monitoring studies on the workers exposed to asbestos and to all other identified carcinogenic substances. The 
development of this review will contribute to incorporate the evidences in the practice of nurses and occupational health staff in industries and public health.

The limitations refer to the inclusion of ten articles with levels of evidence $\mathrm{V}$ or VI in the final sample. This type of studies does not produce strong evidence on the association between carcinogenic agents found in the workplace and the development of lung cancer, as the studies with higher evidence level. The difficulty in accessing the international publications because they are not fully available is another limitation, since that articles on the subject may not have been included.

\section{REFERENCES}

1. Instituto Nacional de Câncer (BR) [Internet]. Rio de Janeiro (RJ): INCA; c20112019 [cited 2019 Jun 10]. Tipos de câncer: câncer de pulmão; [approx. 1 screen]. Available from: https://www.inca.gov.br/tipos-de-cancer/cancer-de-pulmao

2. International Agency for Research on Cancer (FR) [Internet]. Global Cancer Observatory. Lyon: IARC; c2018-2019 [cited 2019 Jun 10]. Available from: http://gco.iarc.fr/

3. Instituto Nacional de Câncer José de Alencar Gomes da Silva (BR). Coordenação de Prevenção e Vigilância. Estimate 2018: incidence of cancer in Brazil. Rio de Janeiro: INCA; 2017 [cited 2019 Jun 10]. Available from: http://coleciona-sus. bvs.br/lildbi/docsonline/get.php?id=1451

4. Eom SY, Yim DH, Lee CH, Choe KH, An JY, Lee KY, et al. Interactions between paraoxonase 1 genetic polymorphisms and smoking and their effects on oxidative stress and lung cancer risk in a Korean population. PLOS One. 2015;10:e0119100. doi: https://doi.org/10.1371/journal.pone.0119100

5. Facina T. Diretrizes para a vigilância do câncer relacionado ao trabalho. Rev Bras Cancerol. 2012;58:279-80.

6. Instituto Nacional de Câncer José Alencar Gomes da Silva (BR). Diretrizes para a vigilância do câncer relacionado ao trabalho. Rio de Janeiro: INCA; 2012 [cited 2019 Jun 10] Available from: http://bvsms.saude.gov.br/bvs/publicacoes/inca/ diretrizes_vigilancia_cancer_trabalho.pdf

7. Organização das Nações Unidas (BR) [Internet]. Rio de Janeiro: UNIC; c20182019 [cited 2019 Jun 10]. Um trabalhador morre a cada 30 segundos no mundo por exposição a substâncias tóxicas, diz ONU; [approx. 1 screen]. Available from: https://nacoesunidas.org/um-trabalhador-morre-a-cada-30-segundos-nomundo-por-exposicao-a-substancias-toxicas-diz-onu/

8. Chagas CC, Guimarães RM, Boccolini PMM. Câncer relacionado ao trabalho: uma revisão sistemática. Cad Saúde Coletiva. 2013;21(2):209-23. doi: https:// doi.org/10.1590/S1414-462X2013000200017

9. Malta DC, Oliveira TP, Vieira ML, Almeida L, Szwarcwal CL. Use of tobacco and exposure to tobacco smoke in Brazil: results from the National Health Survey 2013. Epidemiol Serv Saúde. 2015;24(2):239-48. doi: https://doi.org/10.5123/ S1679-49742015000200006

10. Ministério do Trabalho e Emprego. Portaria interministerial n. ${ }^{\circ}$, de 07 de outubro de 2014. Publica a Lista Nacional de Agentes Cancerígenos para Humanos (LINACH), como referência para formulação de políticas públicas, na forma do anexo a esta Portaria. Brasília (DF); 2014 [cited 2019 Jun 10]. Available from: https://enit.trabalho.gov.br/portal/images/Arquivos_SST/SST_Legislacao/ SST_Legislacao_Portarias_2014/Portaria-Inter-n.-09-LINACH.pdf
11. Souza MT, Silva MD, Carvalho R. Integrative review: what is it? how to do it? Einstein. 2010;8:102-6. doi: https://doi.org/10.1590/s1679-45082010rw1134

12. Mendes KDS, Silveira RCCP, Galvão CM. Revisão integrativa: método de pesquisa para a incorporação de evidências na saúde e na enfermagem. Texto Contexto Enferm. 2008;17(4):758-64. doi: https://doi.org/10.1590/ S0104-07072008000400018

13. Moher D, Liberati A, Tetzlaff J, Altman DG. Principais itens para relatar revisões sistemáticas e meta-análises: a recomendação PRISMA. Epidemiol Serv Saúde. 2015;24(2):335-42. doi: https://doi.org/10.5123/S1679-49742015 000200017

14. Melnyk BM, Fineout-Overholt E. Making the case for evidence-based practice. In: Melnyk BM, Fineout-Overholt E. Evidence based practice in nursing \& healthcare. A guide to best practice. Philadelphia: LippincottWilliams \& Wilkins; 2005. p. 3-24.

15. Wu WT, Lin YJ, Li CY, Tsai PJ, Yang CY, Liou SH, et al. Cancer attributable to asbestos exposure in shipbreaking workers: A matched-cohort study. PLoS One. 2015;10(7):e0133128. doi: https://doi.org/10.1371/journal.pone.0133128

16. Algranti E, Buschinelli JTP, De Capitani EM. Câncer de pulmão ocupacional. J Bras Pneumol. 2010;36(6):784-94. doi: https://doi.org/10.1590/S1806-3713 2010000600017

17. Westberg H, Andersson L, Bryngelsson IL, Ngo Y, Ohlson CG. Cancer morbidity and quartz exposure in Swedish iron foundries. Int Arch Occup Environ Health. 2013;86(5):499-507. doi: https://doi.org/10.1007/s00420-012-0782-4

18. Kishimoto T, Gemba K, Fujimoto N, Onishi K, Usami I, Mizuhashi K, et al. Clinical study of asbestos-related lung cancer in Japan with special reference to occupational history. Cancer Sci. 2010;101(5):1194-8. doi: https://doi.org/ 10.1111/j.1349-7006.2010.01509.x

19. Hosgood HD, Chapman RS, Wei H, He X, Tian L, Liu LZ, et al. Coal mining is associated with lung cancer risk in Xuanwei, China. Am J Ind Med. 2012;55(1):510. doi: https://doi.org/10.1002/ajim.21014

20. Sun Y, Bochmann F, Nold A, Mattenklott M. Diesel exhaust exposure and the risk of lung cancer-a review of the epidemiological evidence. Int J Environ Res Public Health. 2014;11(2):1312-40. doi: https://doi.org/10.3390/ijerph110201312

21. Lacasse Y, Martin S, Gagné D, Lakhal L. Dose-response meta-analysis of silica and lung cancer. Cancer Causes Control. 2009;20(6):925-33. doi: https://doi. org/10.1007/s10552-009-9296-0

22. Doi M, Hattori N, Yokoyama A, Onari Y, Kanehara M, Masuda K, et al. Effect of mustard gas exposure on incidence of lung cancer: a longitudinal study. Am J Epidemiol. 2011;173(6):659-66. doi: https://doi.org/10.1093/aje/kwq426

23. Ahn Y-S, Jeong KS. Epidemiologic characteristics of compensated occupational lung cancers among Korean workers. J Korean Med Sci. 2014;29(11):1473. doi: https://doi.org/10.3346/jkms.2014.29.11.1473

24. Olsson AC, Gustavsson P, Kromhout H, Peters S, Vermeulen R, Brüske I, et al. Exposure to diesel motor exhaust and lung cancer risk in a pooled analysis from case-control studies in Europe and Canada. Am J Respir Crit Care Med. 2011;183(7):941-8. doi: https://doi.org/10.1164/rccm.201006-09400C

25. Liu Y, Steenland K, Rong Y, Hnizdo E, Huang X, Zhang H, et al. Exposure-response analysis and risk assessment for lung cancer in relationship to silica exposure: a 44-year cohort study of 34,018 workers. Am J Epidemiol. 2013;178(9):142433. doi: https://doi.org/10.1093/aje/kwt139

26. Lin CK, Chang YY, Wang J Der, Lee LJH. Increased standardised incidence ratio of malignant pleural mesothelioma in Taiwanese asbestos workers: a 29-year retrospective cohort study. Biomed Res Int. 2015:678598. doi: https://doi. org/10.1155/2015/678598 
27. Garshick E, Laden F, Hart JE, Davis ME, Eisen EA, Smith TJ. Lung cancer and elemental carbon exposure in trucking industry workers. Environ Health Perspect. 2012;120(9):1301-6. doi: https://doi.org/10.1289/ehp.1204989

28. Consonni D, De Matteis S, Lubin JH, Wacholder S, Tucker M, Pesatori AC, et al. Lung cancer and occupation in a population-based case-control study. Am J Epidemiol. 2010;171(3):323-33. doi: https://doi.org/10.1093/aje/kwp391

29. Bugge MD, Kjrheim K, Freland S, Eduard W, Kjuus H. Lung cancer incidence among Norwegian silicon carbide industry workers: associations with particulate exposure factors. Occup Environ Med. 2012;69(8):527-33. doi: https://doi.org/10.1136/0emed-2011-100623

30. Yano E, Wang X, Wang M, Qiu H, Wang Z. Lung cancer mortality from exposure to chrysotile asbestos and smoking: a case-control study within a cohort in China. Occup Environ Med. 2010;67(12):867-71. doi: https://doi.org/10.1136/ oem.2009.051615

31. Consonni D, De Matteis S, Pesatori AC, Bertazzi PA, Olsson AC, Kromhout H, et al. Lung cancer risk among bricklayers in a pooled analysis of case-control studies. Int J Cancer. 2015;136(2):360-71. doi: https://doi.org/10.1002/ijc.28986

32. Brenner DR, Hung RJ, Tsao MS, Shepherd FA, Johnston MR, Narod S, et al. Lung cancer risk in never-smokers: A population-based case-control study of epidemiologic risk factors. BMC Cancer. 2010;10:285. Available from: https:// doi.org/10.1186/1471-2407-10-285

33. Ghanei M, Harandi AA. Lung carcinogenicity of sulfur mustard. Clin Lung Cancer. 2010;11(1):13-7. doi: https://doi.org/10.3816/CLC.2010.n.002

34. Wang X, Lin S, Yano E, Qiu H, Yu ITS, Tse L, et al. Mortality in a Chinese chrysotile miner cohort. Int Arch Occup Environ Health. 2012;85(4):405-12. doi: https:// doi.org/10.1007/s00420-011-0685-9

35. Poinen-Rughooputh S, Rughooputh MS, Guo Y, Rong Y, Chen W. Occupational exposure to silica dust and risk of lung cancer: an updated meta-analysis of epidemiological studies. BMC Public Health. 2016;16:1137. doi: https://doi. org/10.1186/s12889-016-3791-5

36. Chang CJ, Tu YK, Chen PC, Yang HY. Occupational exposure to talc increases the risk of lung cancer: a meta-analysis of occupational cohort studies. Can Respir J. 2017:1270608. doi: https://doi.org/10.1155/2017/1270608

37. Ferrante D, Mirabelli D, Tunesi S, Terracini B, Magnani C. Pleural mesothelioma and occupational and non-occupational asbestos exposure: A case-control study with quantitative risk assessment. Occup Environ Med. 2016;73(3):14753. doi: https://doi.org/10.1136/oemed-2015-102803

38. Swiatkowska B, SzubertZ, Sobala W, Szeszenia-Dabrowska N. Predictors of lung cancer among former asbestos-exposed workers. Lung Cancer. 2015;89(3):2438. doi: https://doi.org/10.1016/j.lungcan.2015.06.013
39. Clin B, Andujar P, Abd Al Samad I, Azpitarte C, Le Pimpec-Barthes F, BillonGalland MA, et al. Pulmonary carcinoid tumors and asbestos exposure. Ann Occup Hyg. 2012;56(7):789-95. doi: https://doi.org/10.1093/annhyg/ mes017

40. Zurbriggen R, Capone L. Enfermedad pulmonar por amianto en trabajadores de acería. Medicina (Buenos Aires). 2013 [citado 2019 mai 20];73(3):22430. Disponible en: http://www.medicinabuenosaires.com/PMID/23732197. pdf

41. Sogl M, Taeger D, Pallapies D, Brüning T, Dufey F, Schnelzer M, et al. Quantitative relationship between silica exposure and lung cancer mortality in German uranium miners, 1946-2003. Br J Cancer. 2012;107(7):1188-94. doi: https:// doi.org/10.1038/bjc.2012.374

42. Tse LA, Yu IS, Au JSK, Qiu H, Wang XR. Silica dust, diesel exhaust, and painting work are the significant occupational risk factors for lung cancer in nonsmoking Chinese men. Br J Cancer. 2011;104(1):208-13. doi: https://doi.org/10.1038/ sj.bjc.6606006

43. Steenland K, Ward E. Silica: a lung carcinogen. CA Cancer J Clin. 2014;64(1):639. doi: http://doi.org/10.3322/caac.21214

44. Silverman DT, Samanic CM, Lubin JH, Blair AE, Stewart PA, Vermeulen R, et al. The diesel exhaust in miners study: a nested case-control study of lung cancer and diesel exhaust. J Natl Cancer Inst. 2012;104(11):855-68. doi: https://doi. org/10.1093/jnci/djs034

45. Järvholm B, Åstrom E. The risk of lung cancer after cessation of asbestos exposure in construction workers using pleural malignant mesothelioma as a marker of exposure. J Occup Environ Med. 2014;56(12):1297-301. doi: https:// doi.org/10.1097/JOM.0000000000000258

46. De Matteis S, Conssoni D, Lubin JH, Tucker M, Peters S, Vermeulen RCh, et al. Impact of occupational carcinogens on lung cancer risk in on general population. Int J Epidemiol. 2012; 41(3):711-21. doi: https://doi. org/10.1093/ije/dys042

47. Algranti E, Saito CA, Carneiro APS, Moreira B, Mendonça EMC, Bussaco MA. The next mesothelioma wave: mortality trends and forecast to 2030 in Brazil. Cancer Epidemiol. 2015;39(5):687-92. doi: https://doi.org/10.1016/j. canep.2015.08.007

48. Ferracini B, Pedra F, Otero U. Asbestos-related cancers in Brazil. Cad Saúde Pública. 2015;31(5): 903-5. doi: https://doi.org/10.1590/0102-311XPE010515

49. Supremo Tribunal Federal (BR) [Internet]. Brasilia, DF: STF; c2017 [cited 2019 Jun 10]. STF reafirma inconstitucionalidade de dispositivo que permitia extração de amianto crisotila; [approx. 1 screen]. Available from: http://www.stf.jus.br/ portal/cms/verNoticiaDetalhe.asp?idConteudo $=363263$

\section{- Corresponding author:}

Christiane Brey

E-mail: christianebrey@gmail.com

\section{Associate editor:}

Cecília Glanzner

Received: 10.29.2019

Editor-in-chief:

Approved: 02.12.2020

Maria da Graça Oliveira Crossetti 